\title{
Split Application of Lime for Acid Soil Amelioration and Better Maize Yield at Yubdo Districts West Wollega Zone, Oromia, Ethiopia
}

\author{
Wegene Negese*, Tamasgen Mosisa, Gelana Mulugeta \\ Oromia Agricultural Research Institute, Haro Sabu Agricultural Research Center, Soil Fertility Improvement \\ Research Team P.O.Box 10, Haro Sabu, Kellem Wollega, Oromia, Ethiopia
}

\begin{abstract}
Soil acidity is one of the major yield limiting factors for crop production in the western of Oromia Region, Ethiopia. A study experiment was done on acid soils to assess the ameliorating ability of lime when applied in split application and its effects on maize yield and selected soil properties in the study area. The experiment comprised six treatments namely $\left[\mathrm{T}_{1}\right]$ :Control (without any input), $\left[\mathrm{T}_{2}\right]$ :Only blanket fertilizer recommendation, $\left[\mathrm{T}_{3}\right]$ :Full dose of lime applied at one time, $\left[\mathrm{T}_{4}\right]: 50 \%$ of the dose applied in the first year and the rest $50 \%$ in the second year, $\left[\mathrm{T}_{5}\right]: 33 \%$ of the dose applied in the first year, 33\% in the second year and the rest 33\% in the third year and $\left[\mathrm{T}_{6}\right]: 25 \%$ of the dose applied in the first year, $25 \%$ in the second year, $25 \%$ in the third year and the rest $25 \%$ in the fourth year and laid out in a randomized complete block design with three replicates. Lime requirement was determined based on exchangeable acidity of the soil. Soil analysis revealed that split lime application at different year raised soil $\mathrm{pH}$ from 5.01 to 5.30 and reduced the exchangeable acidity from 1.90 $0.85 \mathrm{cmolc} / \mathrm{kg}$ of soil. Likewise yield of maize was significantly affected by the treatments. In order to reduce the large amounts of lime at once, split application of lime also gave similar higher yield of maize as that of at once lime application. Therefore, application of lime at once is un-affordable due to large amounts required per hectare of land and split application of lime could be considered as an alternative option for poor resource farmers for sustainable soil health and crop productivity.
\end{abstract}

Keywords: Soil acidity, Split application of Lime, Maize yield, Soil properties

DOI: $10.7176 / \mathrm{JAAS} / 77-04$

Publication date: January $31^{\text {st }} 2022$

\section{Introduction}

Soil acidity is among the major land degradation problem worldwide. It is estimated that over 11 million ha of land is exposed to soil acidity around the world. Tropical and sup tropical regions as well as areas with moderate climatic conditions are mostly affected in soil acidity. Worldwide, $32 \%$ of all arable land is acid and that figure claims to be $50 \%$ in tropics. In this region, high rain fall and temperature are dominating throughout the year round and results into high rate of weathering of the soil, high rate of leaching nutrients from soils, very rapid destruction of soil physical structure and texture, quick and sever erosion of the top soil and acute drought stress are signals of severe soil acidity (Eswaran et al., 1997).

Soil acidity is now a serious threat to crop production in most high lands of Ethiopia. Ethiopian Soil Information System (EthioSIS, 2014) shows about 43\% of the Ethiopian arable land has affected by soil acidity, of these about $28.1 \%$ of soils are dominated by strongly acidic soils ( $\mathrm{pH} 4.1-5.5)$. The main soil forming factors giving rise to increase soil acidity in Ethiopia involve climatic factors such as rainfall, temperature, topographic factors, morphological factors and severe soil erosion ( Mesfin Abebe, 1998). Nitisol/Oxisol zones are the main soil classes dominated by soil acidity. These soils are predominantly acidic and have been found that more than $80 \%$ of the land masses originated from Nitisol are acidic.

Soil acidity is an impediment to agricultural production in areas where heavy rainfall is causing nutrient loss by way of leaching and soil erosion. It is a complex process resulting in the formation of an acid soil due to excessive concentration of non-soluble and toxic ions in the soil solution. In the context of agricultural problem soils, acid soils are soils in which acidity dominates the problems related to agricultural land use. Consequently, the level of $\mathrm{Al}^{3+}$ and $\mathrm{H}^{+}$becomes too high causing the soil's negatively charged CEC to be overwhelmingly blocked with positively charged $\mathrm{H}$ and $\mathrm{Al}$, and the nutrients needed for plant growth become unavailable resulting into inhibition of root growth and plant development (Juo et al. 1995).

Crop yield in acid soils are frequently reduced by $40-50 \%$ and can be reduced to zero. This adverse effect is attributed to the fact that soil $\mathrm{pH}$ affects nutrient solubility and influences the sorption or precipitation of nutrients with $\mathrm{Al}$ and $\mathrm{Fe}$ (Hue, 1992). The principal direct factors causing poor growth and low yield of crops are $\mathrm{Al}$ and $\mathrm{Mn}$ toxicity and $\mathrm{Mg}, \mathrm{Ca}$ and Mo deficiency. Added to this list is $\mathrm{P}$ deficiency caused by adsorption of $\mathrm{P}$ to colloidal fractions in acid soils and conversion to insoluble $\mathrm{Al}$ and/or Fe compounds (von Uexkull and Bosshart, 1989). Increased soil acidity is likely to lead to poor plant growth and water use efficiency as a result of nutrient deficiencies and induced $\mathrm{Al}$ and Mn toxicity. 
The population of Ethiopia is currently growing at a fast rate and demands an increasing proportion of agricultural products. On the other hand, growth in food production is not in equal footings with population pressure. Strengthening food production capability of the country by exploiting its existing human and natural resources is critical option to prevent the existing situation. Amid the various opportunities sought to increase agricultural development, exploitation of degraded lands devoid of crop production as consequence of soils acidity is one of the area of priority to tackle. The research approach used so far gave little attention to this threatening problem and it need for urgent solution to minimize its adverse impact and foster its contribution to the country's food security and poverty eradication efforts. Therefore the objective of this experiment was to assess the ameliorating ability of lime when applied in split application and determine effects of split application of lime on maize yield and selected soil properties in the study area.

\section{Materials and Methods}

\subsection{Description of the study area}

The study was conducted at FTC of Wera Gutu Kebele, Yubdo district, West Wollega Zone Oromia, Ethiopia. The district is located at a distance of $520 \mathrm{~km}$, west of the capital Addis Ababa. Geographically, the district lies at $09^{\circ} 01.947^{\prime} \mathrm{N}$ latitude and $035^{\circ} 20.067^{\prime} \mathrm{E}$ longitude with an altitude ranges from $1600-1800$ meters above sea level. The major rainy seasons in the district from April-November. The annual temperature ranges from 16-32 ${ }^{\circ} \mathrm{C}$ and the annual rainfall is ranges from 1600-2000 $\mathrm{mm}$. The predominant soil type in southwest and western Ethiopia in general and the study area in particular is Nitisols according to (FAO, 2001) soil classification system.
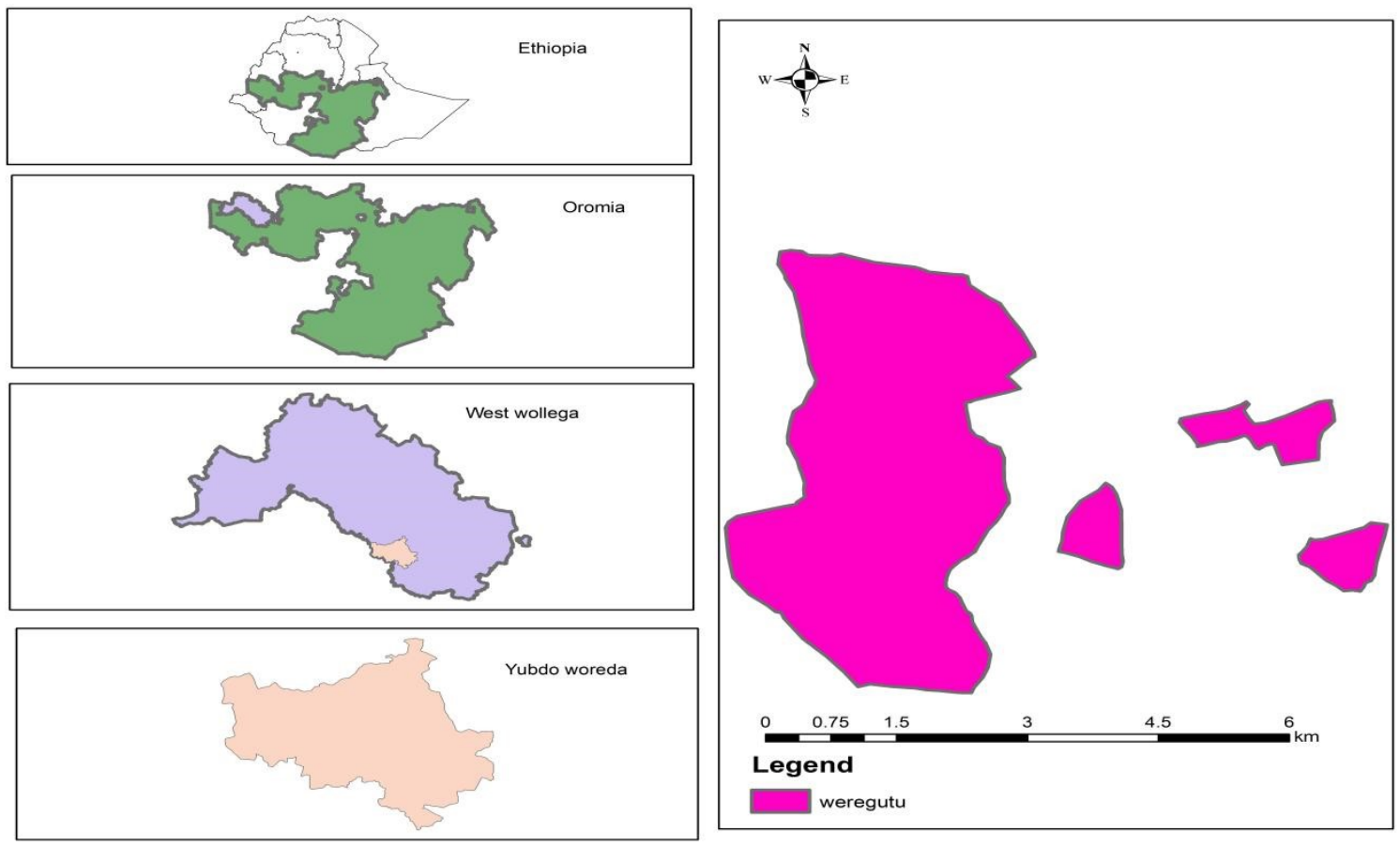

Figure1. Location map of the study area

\subsection{Experimental Materials and Design}

Field experiment on maize crop was established for four cropping seasons(2017-2020) on acid soils located at Yubdo districts of Wera Gutu FTC kebela of West Wollega zone, Oromia. The lime recommendation on this study was based on the amount of exchangeable acidity measured by the lime requirement of soil test. The amount of lime applied at each level was calculated based on the basis of exchangeable $\mathrm{Al}^{3+}$ and $\mathrm{H}^{+}$of the site. The experiment was laid out by RCBD with three replications. The treatments are arranged as follows. Control(without any input), Only blanket fertilizer recommendation, Full dose of lime applied at one time, 50\% of the dose applied in the first year and the rest $50 \%$ in the second year, $33 \%$ of the dose applied in the first year, $33 \%$ in the second year and the rest $33 \%$ in the third year and $25 \%$ of the dose applied in the first year, $25 \%$ in the second year, $25 \%$ in the third year and the rest $25 \%$ in the fourth year. The blanket recommended fertilizer was applied uniformly to all treatments. Lime was uniformly applied to the plots as per treatment by hand and incorporated into the soil a month before planting. Application of Urea was in split. The plots were reserved permanently for the duration of the experiments to observe effects of split application of lime. Initial composite soil samples collected at the depth of $0-20 \mathrm{~cm}$ soil before lime application were analyzed for soil $\mathrm{pH}$, available 
phosphorus and exchangeable acidity. Similarly, After harvest soil samples were also collected from each plots and analyzed for soil $\mathrm{pH}$, available phosphorus and exchangeable acidity, exchangeable bases $(\mathrm{Ca}$ and $\mathrm{Mg})$ and Cation exchangeable capacity ( CEC) . Maize (BH -661 variety) which is the main staple crop in the area was used as the test crop. The agronomic recommendation of inorganic fertilizer rate for maize in the area was used as per treatment. Soil and agronomic data was collected and analyzed. Initial lime needed for the site was 5960 $\mathrm{kg} / \mathrm{ha}$ and splited to the plots based on plot size. Based on initial soil test data, the treatments were arranged as below in (Table 1).

Table 1. Treatment arrangements

\begin{tabular}{lllll}
\hline Treatments & \multicolumn{4}{c}{ Years } \\
\cline { 2 - 5 } & $\mathbf{2 0 1 6 / 1 7}$ & $\mathbf{2 0 1 7 / 1 8}$ & $\mathbf{2 0 1 8} / \mathbf{1 9}$ & $\mathbf{2 0 1 9} / \mathbf{2 0}$ \\
\hline T1 & $2.235 \mathrm{~kg}$ & $2.235 \mathrm{~kg}$ & $2.235 \mathrm{~kg}$ & $2.235 \mathrm{~kg}$ \\
T2 & $2.98 \mathrm{~kg}$ & $2.98 \mathrm{~kg}$ & $2.98 \mathrm{~kg}$ & 0 \\
T3 & $4.47 \mathrm{~kg}$ & $4.47 \mathrm{~kg}$ & 0 & 0 \\
T4 & $8.94 \mathrm{~kg}$ & 0 & 0 & 0 \\
T5 & Control(-ve) & 0 & 0 & 0 \\
T6 & Only Fertlizer & Only Fertlizer & Only Fertlizer & Only Fertlizer \\
\hline
\end{tabular}

\subsection{Statistical Analysis}

The collected data was entered into Microsoft excel and subjected to analysis of variance (ANOVA) using SAS software version 9.2 (SAS Institute, 2002).

\section{Results And Discussion}

Selected chemical properties of the soil prior to the application of the treatments are presented in (Table 2).

Table 2. Initial selected soil chemical properties and Lime Requirement

\begin{tabular}{llll}
\hline $\mathbf{p H}\left(\mathbf{H}_{2} \mathbf{O}\right)$ & Av. P (Mg/Kg Soil) & Exch. Acidity $\left(\mathbf{A l} \mathbf{3}^{\mathbf{3}}+\mathbf{H}^{+}\right)$ & Lime Requirement(kg/ha) \\
\hline 4.63 & 4.70 & 3.97 & 5960
\end{tabular}

Exch.Acidity = Exhangeable acidity; OC = Organic carbon; Av. P = Available phosphorous;

\subsection{Effects of split application of lime on some soil chemical properties}

Analysis of variance showed that soil $\mathrm{pH}$ and available phosphorous were significantly increased while, exchangeable acidity decreased due to split application of lime as compared to control and inorganic fertilizer application treatments. Application of split lime application slightly increased soil pH from 5.01 to 5.30 (Table 3 ). The increment of soil pH in response to split application of lime at different rates was about $5.47 \%$ over the control (no lime applied soil) and $2.45 \%$ over blanket recommended inorganic fertilizer. On the other hand, split application of lime significantly reduced the exchangeable acidity from $1.90-0.85$ over the control plot . Generally, there was no significant difference among different split application of lime in terms of soil $\mathrm{pH}$, available $\mathrm{P}$, exchangeable acidity, exchangeable bases $(\mathrm{Ca}$ and $\mathrm{Mg})$ and $\mathrm{CEC}$. However, split application of lime gave significantly higher values of soil $\mathrm{pH}$, available $\mathrm{P}$, exchangeable acidity, exchangeable bases $(\mathrm{Ca}$ and $\mathrm{Mg})$ and CEC over the control and inorganic fertilizer application only.

In general liming of acidic soils could increase soil $\mathrm{pH}$, which enhances the release of phosphate ions fixed by $\mathrm{Al}$ and $\mathrm{Fe}$ ions into the soil solution. Therefore, lime application by different method is important for the management of acid soil.

Table 3. Mean effects of split application of lime on selected soil chemical properties

\begin{tabular}{|c|c|c|c|c|c|c|c|}
\hline \multirow[t]{2}{*}{ Treatments } & \multirow{2}{*}{$\begin{array}{l}\text { Soil pH } \\
(1: 2.5 \\
\left.\mathrm{H}_{2} \mathrm{O}\right)\end{array}$} & \multirow{2}{*}{$\begin{array}{l}\text { Exch. } \\
\text { Acidity } \\
\text { (cmol(+) } \\
\text { /kg soil) }\end{array}$} & \multirow{2}{*}{$\begin{array}{l}\text { Av.P } \\
(\mathbf{p p m})\end{array}$} & \multicolumn{2}{|c|}{$\operatorname{cmol}(+) / k g$ soil) } & \multirow[t]{2}{*}{$\mathrm{OC}(\%)$} & \multirow{2}{*}{$\begin{array}{l}\mathrm{CEC}(\mathrm{cmol}(+) \\
/ \mathrm{kg} \text { soil })\end{array}$} \\
\hline & & & & $\mathrm{Ca}$ & Mg & & \\
\hline Control & $5.01 b$ & $1.90 \mathrm{a}$ & $1.48 \mathrm{c}$ & $4.50 \mathrm{dc}$ & $6.00 \mathrm{a}$ & $2.36 b$ & $17.56 a$ \\
\hline $25 \%$ lime every year & $5.28 \mathrm{a}$ & $1.19 \mathrm{~b}$ & $2.28 \mathrm{ba}$ & $5.38 \mathrm{bc}$ & $8.20 \mathrm{a}$ & $3.36 \mathrm{a}$ & $19.53 \mathrm{ba}$ \\
\hline $33 \%$ lime every year & $5.30 \mathrm{a}$ & $1.03 \mathrm{~b}$ & $2.72 \mathrm{a}$ & $5.96 \mathrm{ba}$ & $9.53 \mathrm{a}$ & $3.21 \mathrm{ba}$ & $20.33 \mathrm{ba}$ \\
\hline $50 \%$ lime every year & $5.28 \mathrm{a}$ & $0.92 b$ & $2.38 \mathrm{ba}$ & $6.65 \mathrm{a}$ & $9.01 \mathrm{a}$ & $3.17 \mathrm{ba}$ & $20.66 \mathrm{ba}$ \\
\hline $\begin{array}{l}\text { Full dose of lime } \\
(100 \%) \text { at once }\end{array}$ & $5.27 \mathrm{a}$ & $0.85 b$ & $2.37 \mathrm{ba}$ & $6.85 a$ & $9.26 \mathrm{a}$ & $3.19 \mathrm{ba}$ & $22.36 \mathrm{a}$ \\
\hline Only Fertlizer & $5.17 \mathrm{ba}$ & $1.71 \mathrm{a}$ & $1.74 \mathrm{bc}$ & $3.65 \mathrm{~d}$ & $7.68 \mathrm{a}$ & $3.20 \mathrm{ba}$ & $15.10 \mathrm{c}$ \\
\hline Lsd & 0.186 & 0.409 & 0.704 & 1.132 & 3.618 & 0.911 & 4.00 \\
\hline $\mathrm{CV}(0.05)$ & 1.96 & 17.91 & 17.70 & 11.31 & 24.01 & 16.23 & 11.41 \\
\hline
\end{tabular}

Exch. Acidity $=$ Exhangeable acidity; $\mathrm{OC}=$ Organic carbon; $\mathrm{Av} . \mathrm{P}=$ Available phosphorous; $\mathrm{Ca}=\mathrm{Calcium} ; \mathrm{Mg}=$ Magnesium; CEC = Cation exchange capacity. 


\subsection{Effect of split application of lime on maize yield}

The findings of the study revealed that the yield and yield components of maize responded positively and significantly to the split application of lime and once lime application even though they are statistically nonsignificant (Table 4). All split lime application treatments gave significantly higher grain yield of maize over control and inorganic fertilizers only. Inorganic fertilizers are vital for high yields, but their use is saddled with many ramifications such as soil acidification. The increase in crop yield through application of lime may be attributed to the neutralization of $\mathrm{Al}^{3+}$, supply of $\mathrm{Ca}^{2+}$ and increasing availability of some plant nutrients like Phosphorous. Furthermore, increase in grain yield with the application of lime is attribute to its favorable effect on the chemical properties of the soil.

Table 4. Effect of split application of lime on maize grain yield $\left(\mathrm{kg} \mathrm{ha}^{-1}\right)$

\begin{tabular}{lllll|l}
\hline Treatment & \multicolumn{3}{c}{ Grain yield (kg ha-1) in year } & \multirow{2}{*}{ Mean } \\
\cline { 2 - 5 } & $\mathbf{2 0 1 6 / 1 7}$ & $\mathbf{2 0 1 7 / 1 8}$ & $\mathbf{2 0 1 8} / \mathbf{1 9}$ & $\mathbf{2 0 1 9 / 2 0}$ & \\
\hline Control & $2981.1 \mathrm{~b}$ & 3688.7 & $2355.3 \mathrm{~b}$ & $2970.0 \mathrm{~b}$ & 2998.78 \\
25\% lime every year & $5820.0 \mathrm{a}$ & 6227.8 & $6120.0 \mathrm{a}$ & $4930.0 \mathrm{a}$ & 5774.45 \\
33\% lime every year & $5461.1 \mathrm{a}$ & 6001.9 & $5776.7 \mathrm{a}$ & $5470.0 \mathrm{a}$ & 5677.42 \\
50\% lime every year & $6330.0 \mathrm{a}$ & 6561.1 & $6368.0 \mathrm{a}$ & $5493.3 \mathrm{a}$ & 6188.10 \\
Full dose of lime (100\%) at the first & $5637.8 \mathrm{a}$ & 7194.4 & $5903.3 \mathrm{a}$ & $5366.7 \mathrm{a}$ & 6025.55 \\
year (at once) & & & & & \\
Only Fertlizer & $5330.0 \mathrm{a}$ & 5746.3 & $5270.0 \mathrm{a}$ & $5130.0 \mathrm{a}$ & 5369.07 \\
\hline Lsd & 1894.3 & 2195.5 & 1303.4 & 1688.9 & \\
CV $(0.05)$ & 19.79 & 20.44 & 13.52 & 18.97 & \\
\hline
\end{tabular}

\section{Summary and Conclusions}

Soil acidity is a major yield-limiting factor for crop production nationwide and in Ethiopia particularly, in the western region of the country, which receive high rainfall to leach down basic cations of the soils. Even though soil acidity is major problems in the study area, no studies have been conducted on split application of lime for soil acidity management in the area. Therefore, this study was conducted to to assess the ameliorating ability of lime when applied in split application and determine its effects on maize yield and selected soil properties in the study area.

The study findings support the idea that liming ameliorates soil acidity and improves soil chemical property making it favorable for the crop growth. Split application of lime increased the soil $\mathrm{pH}$ from strongly acidic to medium range $(\mathrm{pH} 4.8-5.30)$ and reduced the exchangeable acidity from $1.90-0.85 \mathrm{cmolc} / \mathrm{kg}$ of soil. Through its ameliorating effects and thus indirectly favoring the creation of more suitable medium for nutrient uptake by the crop. This condition creates a favorable soil environment that enables efficient use of nutrients which ultimately resulted in better performance in terms of yield and yield components of the crop. Liming can be used to reduce soil acidity. They can be used either splitly or at once. The use of split application of lime along with recommended rate of inorganic fertilizer significantly influenced grain yield of maize in similar way as that of at once lime application. Therefore, it is advisable for farmers to use lime in split or at once to maximize maize grain yield on acid soils of western Oromia where soil acidity is a major production constraint. Lime recommendations have to be as specific as possible, taking soils, crops, time and place into account. Other alternatives such as choice of acid-tolerant crop varieties and use of organic fertilizer may further reduce the amounts of lime required and make farming more attractive.

\section{Acknowledgement}

The authors would like to thanks Oromia Agricultural Research Institute for financial support and Haro Sabu Agricultural Research Center for provision of facility during research work. The authors also thankful to all Soil Fertility Improvement for their trial management and data collection.

\section{References}

Eswaran, H, Reich, P and Beinroth, F. 1997. Global distribution of soil with acidity. P159-164. In:Moriz, A.C., Furlani, A.M.C, Schaffert, R.E., Fageria, N.K., Rosalem, C.A., Contarella, H. (Eds). Plant- soil interactions at low ph Brazilian soil sci. society. Campinas/Vicosa, Brazil

Fox, R.H. 1979.soil pH, aluminum saturation and corn grain yield. soil sci.127:330-334

Fox, R.H. and Kamprath,E.J. 1970. Phosphate sorption isothrms for evaluating the phosphate requirements os soil. soil sci. soc. Am. Proc.34:902-907

Hue, N,V. 1992. Correcting soil acidity of a highly weathered ultisol with chicken manure and sewage sludge. comm. soil. sci. plant anal.23:241-264

Kamprath, E.J.1984. Crop response to lime on soils in the tropics p 341-348. In Adams F. (ed). soil acidity and 
liming. ASA, Madison, Wisconsis.

Mesfin Abebe. 1998. Nature and management of Ethiopian soils. A.U.A. Ethiopia

Pearson, R.W. 1975. Soil acidity and liming in the humid tropics. Int. Agri. Bull. 30. cornell Univ. New York Schlede, H. 1989. Distribution of acid soils and liming materials in Ethiopia. Ethiopian Institute of Geological Survey. Report Note 326

Takow, J., Chase, R.G. and Hossner, L.R. 1991. Acid soil profiles of the semi arid and sub humid tropics in central and West Africa. P. 313-330. In: Plant- soil interactions at low pH. Kluwer Acadamic publisher

\section{Figure 2: Some experimental figures during the study time}
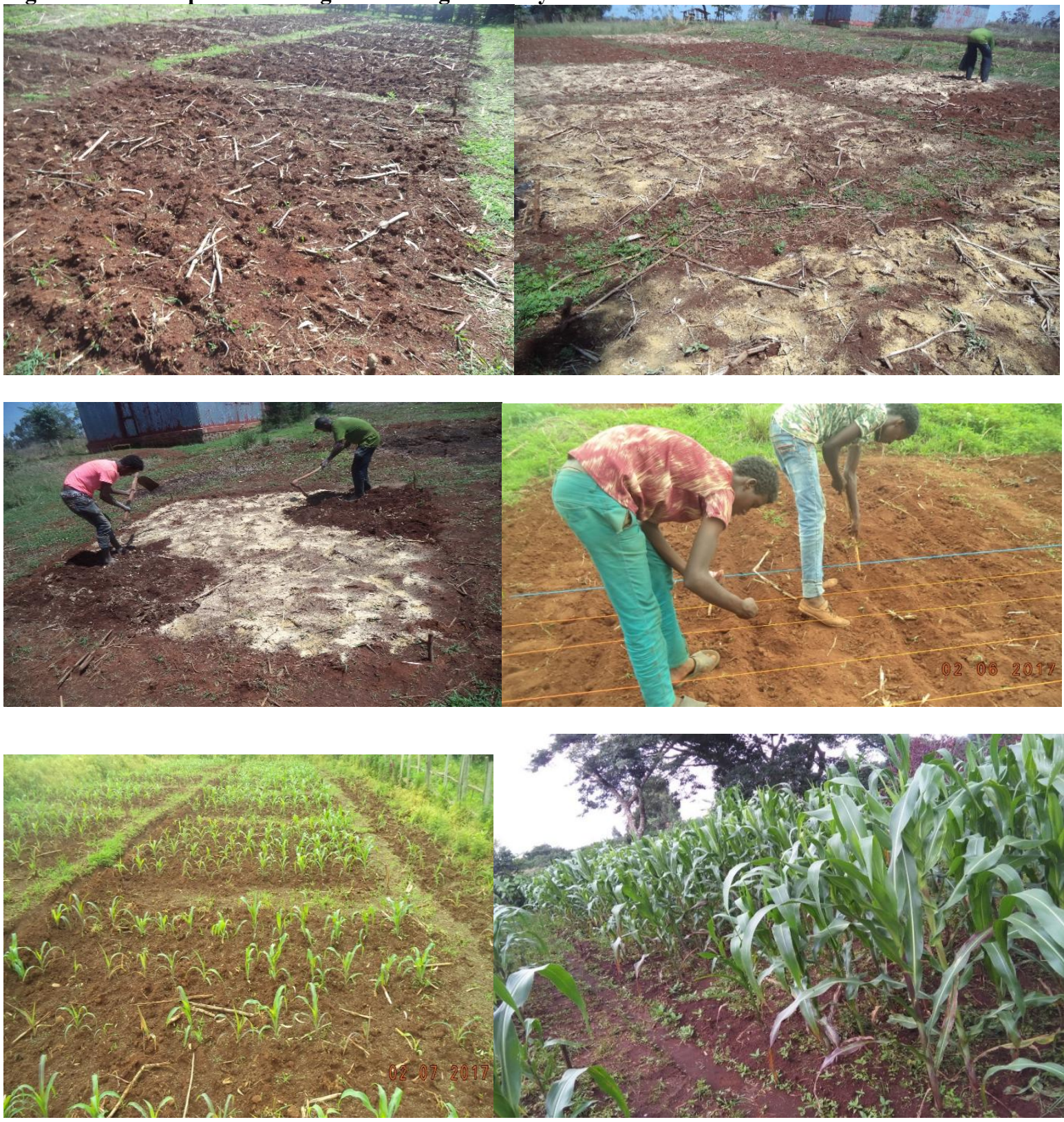